\title{
ASPEK SOSIOEKOLOGIS USAHATANI KOPI ARABIKA DI DATARAN TINGGI KABUPATEN SIMALUNGUN SUMATERA UTARA
}

\author{
Jef Rudiantho Saragih \\ Program Studi Agribisnis Fakultas Pertanian Universitas Simalungun \\ E-mail: jefsaragih@ymail.com
}

\begin{abstract}
ABSTRAK. Penelitian ini bertujuan untuk mengetahui pengaruh aspek sosioekologis terhadap produksi kopi arabika dengan menggunakan persamaan regresi majemuk dan diduga dengan program SPSS 22. Sampel berjumlah 58 rumah tangga petani. Tingkat partisipasi petani mengikuti pelatihan hanya 30\%. Aspek-aspek yang perlu ditingkatkan adalah penggunaan pohon pelindung legum (26\%), jumlah pohon pelindung (67 pohon/ha), pemangkasan tanaman kopi (43\%), pengembalian kulit kopi sebagai mulsa (57\%), dan menyediakan tempat terpisah untuk menyimpan pestisida (41\%). Sementara aspek ekologis yang sudah baik adalah penggunaan pupuk organik (93\%) dan penggunaan masker atau pengaman saat mengaplikasikan pestisida. Aspek ekologis yang perlu diminimalkan adalah penggunaan herbisida untuk mengendalikan gulma (91\%). Aspek sosial dan ekologi secara bersama berperan penting pada usahatani kopi arabika. Aspek ekologi memiliki multiperan, yaitu peningkatan kuantitas produksi, peningkatan kualitas, dan keberlanjutan lingkungan. Partisipasi petani dalam pelatihan, jumlah pohon pelindung legum, dan praktik pemangkasan tanaman kopi, berpengaruh positif dan nyata terhadap produksi kopi arabika. Sementara umur, tingkat pendidikan, jumlah pohon pelindung, penggunaan pupuk organik, dan penggunaan kulit buah kopi sebagai mulsa, berpengaruh positif dan tidak nyata terhadap produksi kopi arabika.
\end{abstract}

Kata kunci: sosioekologis, produksi, kopi arabika

\section{SOCIOECOLOGICAL ASPECT OF ARABICA COFFEE FARMING IN HIGHLAND OF SIMALUNGUN DISTRICT NORTH SUMATERA}

\begin{abstract}
The research aim is to analize of socioecological effect on arabia coffee production in farmer level. Data is analized with multiple regression model and parameter is estimated with SPSS 22. Data were compilated for 58 farmer household. Socioecological aspect has important role on arabica coffee farming. Farmer's participation in training is 30\%. Ecological aspects that need to be improved are use of legume tree (26\%), shade tree population (67 trees/ha), coffee pruning (43\%), coffee bark as mulch (57\%), and separate store for pesticide (41\%). Meanwhile the ecological aspects that well done is use of organic fertilizer (93\%), and use mask when apply pesticide (67\%). Ecological aspect that need to be minimized is use herbicide to control weed (91\%). Ecological aspect has multiple role: enhancing of production quantity, quality, and environment sustainability. Farmer's participation in farm training, population of legume tree, and coffee pruning give positive and significant effect on coffee production. Meanwhile, age, education, population of shade tree, and coffee bark as mulch give positive and nonsignificant effect on arabica coffee production.
\end{abstract}

Key words: socioecological, production, arabica coffee

\section{PENDAHULUAN}

Komoditas kopi merupakan komoditas ekspor penting di Indonesia. Bahkan kopi merupakan komoditas terpenting kedua dalam perdagangan internasional (Gregory dan Featherstone, 2008; Amsalu dan Ludi, 2010). Indonesia berada pada posisi ketiga sebagai produsen kopi terbesar di dunia, setelah Brazil dan Vietnam (ICO, 2015).

Kopi arabika merupakan kopi terpenting dalam perdagangan global karena citarasa yang lebih baik dibandingkan dengan jenis kopi lainnya. Penghasil kopi arabika terbesar di Indonesia adalah Provinsi Sumatera Utara (Ditjen Perkebunan, 2015). Persaingan perdagangan kopi global menjadi semakin ketat akibat tuntutan konsumen akan produk kopi berkualitas tinggi. Produk kopi berkualitas dicerminkan dari sertifikasi kopi dari berbagai wilayah produsen kopi di dunia. Indikator kualitas kopi dalam berbagai program sertifikasi kopi umumnya ditekankan dalam aspek sosial dan ekologi. Aspek sosial seperti pemberdayaan petani dan perlin- dungan pekerja, sementara aspek ekologi adalah halhal yang berkaitan dengan perlindungan lingkungan atau penerapan produksi kopi berkelanjutan dari aspek lingkungan hidup.

Permasalahan mendasar usahatani kopi arabika di Sumatera Utara adalah masih rendahnya kualitas manajemen usahatani bila dikaitkan dengan aspek sosial dan aspek ekologi tersebut. Saragih (2012a) menemukan bahwa tingkat pendidikan kepala rumah tangga dan pengalaman usahatani tidak berpengaruh nyata terhadap produksi kopi arabika. Kondisi ini memberikan dasar pemikiran bahwa pengalaman (lamanya) petani melakukan usahatani kopi arabika tidak berkontribusi signifikan bagi peningkatan produktivitas. Patut diduga, pengalaman praktis dalam bentuk pelatihan yang gayut dinilai lebih memberikan kontribusi bagi perbaikan kinerja usahatani.

Dari aspek ekologi, antara lain ditemukan bahwa $50 \%$ petani belum mengetahui manfaat pohon pelindung bagi tanaman kopi. Padahal berbagai penelitian menemukan bahwa pohon pelindung berperan positif dalam 
meningkatkan kualitas kopi. Peran positif pohon pelindung dalam kualitas kopi ditemukan oleh Yadessa et al. (2008) bahwa spesies pohon pelindung berpengaruh signifikan terhadap kualitas kopi secara keseluruhan. Penelitian Moreira et al. (2008) di wilayah produsen kopi arabika terbesar di dunia di Selatan negara bagian Minas Gerais, Brazil, menyimpulkan bahwa terdapat kecenderungan kualitas kopi yang lebih baik pada sistem usahatani kopi berpelindung.

Dari sisi usahatani, Vossen (2005) menemukan bahwa pohon pelindung berfungsi sebagai pencegah terjadinya over-bearing karena pengurangan intensitas cahaya. Disamping itu, pohon pelindung juga mencegah tanaman mati pucuk sehingga masa produktifnya lebih panjang.

Selain itu, praktik usahatani yang baik dari aspek ekologi seperti penggunaan pupuk organik dan pemangkasan tanaman kopi, masih kurang diadopsi oleh petani di dataran tinggi Kabupaten Simalungun. Lemahnya kedua aspek ini mengakibatkan produktivitas kopi arabika di Kabupaten Simalungun masih relatif rendah, hanya sekitar 50-65\% dari produksi potensialnya (Saragih, 2012b).

Penelitian ini ingin mengetahui pengaruh aspek sosioekologis usahatani kopi arabika di dataran tinggi Kabupaten Simalungun dalam menemukan rekomendasi perbaikan aspek sosioekologis untuk meningkatkan produktivitas sekaligus keberlanjutan produksi kopi arabika.

\section{METODE}

Penelitian dilakukan di Desa Sait Buntu Saribu, Kecamatan Pamatang Sidamanik dan Desa Sirube-rube Gunung Purba, Kecamatan Dolok Pardamean, keduanya di Kabupaten Simalungun, Provinsi Sumatera Utara. Lokasi penelitian berada pada dataran tinggi dengan ketinggian sekitar 1.000 meter di atas permukaan laut. Data usahatani dikumpulkan pada bulan Juli-Agustus 2015. Sampel penelitian adalah 58 rumah tangga petani kopi arabika di dua desa yang diambil dengan metode acak sederhana (simple random method) dari kerangka sampel (sample frame) anggota pada enam kelompok tani.

Aspek sosial dan ekologis dianalisis secara deskriptif dan inferensia. Umur petani, pendidikan formal, partisipasi pelatihan, penggunaan pohon pelindung legum, jumlah pohon pelindung, pemangkasan tanaman kopi, pengembalian kulit kopi sebagai mulsa, penyimpanan pestisida, penggunaan pupuk organik, penggunaan masker atau pengaman saat mengaplikasikan pestisida, dan penggunaan herbisida untuk mengendalikan gulma; dianalisis secara deskriptif. Pengujian inferensia dilakukan melalui model regresi majemuk dimana parameter regresi diduga dengan menggunakan program SPSS versi 22.

Model regresi majemuk yang disusun menggunakan produksi kopi arabika sebagai variabel terikat.
Variabel bebas yang dimasukkan ke dalam model terdiri atas aspek sosial dan aspek ekologi. Aspek sosial adalah umur kepala keluarga, pendidikan formal kepala keluarga, partisipasi mengikuti pelatihan; sementara aspek ekologi adalah jumlah pohon pelindung jenis legum, jumlah pohon pelindung, pemangkasan tanaman kopi, penggunaan pupuk organik, dan pengembalian kulit kopi sebagai mulsa. Model yang disusun adalah:

$Y_{i}=a+b_{1} X_{1}+b_{2} X_{2}+b_{3} D_{1}+b_{4} D_{2}$ $+b_{5} X_{3}+b_{6} D_{3}+b_{7} D_{4}+b_{8} D_{5}$

dimana $Y_{i}$ adalah produksi kopi arabika (kg/tahun), $a$ adalah konstanta, $b_{1} \ldots b_{8}$ adalah koefisien regresi, $X_{1}$ adalah umur kepala keluarga (tahun), $X_{2}$ adalah pendidikan formal kepela keluarga (tahun), $X_{3}$ adalah jumlah pohon pelindung, $D_{1}$ adalah variabel dummy partisipasi petani mengikuti pelatihan usahatani (1 jika petani pernah mengikuti pelatihan, 0 jika tidak pernah), $D_{2}$ adalah variabel dummy pohon pelindung jenis legum (1 jika petani menggunakan sebagian pohon pelindung dari jenis legum, 0 jika tidak menggunakan pohon jenis legum), $D_{3}$ adalah variabel dummy pemangkasan tanaman kopi (1 jika petani melakukan pemangkasan tanaman kopi, 0 jika tidak melakukan pemangkasan), $D_{4}$ adalah variabel dummy penggunaan pupuk organik (1 jika petani menggunakan pupuk organik, 0 jika tidak menggunakan pupuk organik), dan $D_{5}$ adalah variabel dummy penggunaan kulit kopi sebagai mulsa (1 jika petani mengembalikan kulit kopi ke kebun, 0 jika tidak).

Pengujian yang dilakukan adalah uji normalitas, uji heteroskedastisitas, uji multikolinieritas, uji kesesuaian model, uji F, dan uji t.

\section{HASIL DAN PEMBAHASAN}

\section{Karakteristik Sosioekologis Usahatani Kopi Arabika}

Petani kopi arabika di dataran tinggi Kabupaten Simalungun umumnya masih usia produktif dengan ratarata 40 tahun. Pendidikan formal yang ditempuh hanya sampai sekolah menengah pertama (Tabel 1). Sebagian besar petani $(62 \%)$ belum pernah mengikuti pelatihan usahatani kopi arabika. Sebanyak 38\% petani pernah mengikuti pelatihan yang berkaitan dengan praktik usahatni kopi arabika yang baik, terutama dari aspek ekologi. Beberapa modul yang pernah dipelajari dalam pelatihan adalah manfaat pohon pelindung, pemangkasan tanaman kopi, pengendalian hama dan penyakit, pengendalian penggerek buak kopi (PBKo), dan pelatihan buku usahatani. Frekuensi petani mengikuti pelatihan adalah rata-rata dua kali per tahun.

Penggunaan pohon pelindung legum masih sangat rendah. Hanya 26\% petani menggunakan jenis legum sebagai pohon pelindung dengan populasi yang sangat rendah yaitu 5-10 pohon/ha. Sementara populasi pohon pelindung (legum dan nonlegum), juga masih relatif 
Tabel 1. Karakteristik Sosioekologis Usahatani Kopi Arabika

\begin{tabular}{|c|c|c|c|}
\hline No. & $\begin{array}{l}\text { Karakteristik } \\
\text { sosioekologis }\end{array}$ & $\begin{array}{c}\text { Rata- } \\
\text { rata }\end{array}$ & $\begin{array}{c}\text { Simpangan } \\
\text { baku }\end{array}$ \\
\hline 1 & Umur petani (tahun) & 40 & 801,889 \\
\hline 2 & $\begin{array}{l}\text { Pendidikan formal } \\
\text { (tahun) }\end{array}$ & 10 & 9,507 \\
\hline 3 & $\begin{array}{l}\text { Partisipasi pelatihan } \\
(\%)\end{array}$ & 38 & 0,489 \\
\hline 4 & $\begin{array}{l}\text { Pelindung legum } \\
(\%)\end{array}$ & 26 & 0,442 \\
\hline 5 & $\begin{array}{l}\text { Pohon pelindung } \\
\text { (pohon/ha) }\end{array}$ & 67 & 66,215 \\
\hline 6 & $\begin{array}{l}\text { Pemangkasan } \\
\text { tanaman kopi (\%) }\end{array}$ & 43 & 0,500 \\
\hline 7 & Pupuk organik (\%) & 93 & 0,256 \\
\hline 8 & $\begin{array}{l}\text { Kulit kopi sebagai } \\
\text { mulsa (\%) }\end{array}$ & 57 & 0,500 \\
\hline 9 & $\begin{array}{l}\text { Penggunaan } \\
\text { herbisida }(\%)\end{array}$ & 91 & 0,283 \\
\hline 10 & $\begin{array}{l}\text { Tempat pestisida } \\
\text { terpisah }(\%)\end{array}$ & 41 & 0,497 \\
\hline 11 & $\begin{array}{l}\text { Pengaman aplikasi } \\
\text { pestisida }(\%)\end{array}$ & 67 & 0,473 \\
\hline
\end{tabular}

rendah yaitu rata-rata 67 pohon/ha. Jenis pohon legum yang ditanam petani adalah dadap (Erythrina lithosfera), petai (Parkia spiciosa), dan sengon (Paraserianthes falcataria). Pohon pelindung nonlegum diantaranya suren (Tona sinensis), jengkol (Pithecollobium jiringa), durian (Durio zibethinus), dan alpukat (Parsea gratissima).

Aspek ekologis yang perlu ditingkatkan adalah penggunaan pohon pelindung legum (26\%), jumlah pohon pelindung (67 pohon/ha), pemangkasan tanaman kopi (43\%), pengembalian kulit kopi sebagai mulsa (57\%), dan menyediakan tempat terpisah untuk menyimpan pestisida (41\%). Peningkatan aspek-aspek ini di tingkat petani tergantung pada petani dalam membuat keputusan di usahataninya. Namun demikian, petani perlu memeroleh informasi secara mandiri maupun melalui penyuluhan. Malta (2016) menyimpulkan bahwa dalam pengambilan keputusan untuk keberhasilan usahatani diperlukan keaktifan mencari informasi yang berhubungan dengan usahatani dan interaksi dengan penyuluh. Untuk itu, diperlukan juga motivasi bagi petani agar aktif mengakses informasi yang berhubungan dengan usahatani. Selain itu, penyuluh dan lembaga penyuluhan mengintensifkan penyuluhan berdasarkan kebutuhan dan masalah petani. Sementara aspek ekologis yang sudah baik adalah penggunaan pupuk organik (93\%) dan penggunaan masker atau pengaman saat mengaplikasikan pestisida (67\%). Aspek ekologis yang perlu diminimalkan adalah penggunaan herbisida untuk mengendalikan gulma (91\%).

\section{Uji Normalitas}

Dua pendekatan digunakan untuk menguji normalitas data: scatter plot dan metode kurva normal. Metode scatter plot (Gambar 1) menunjukkan data menyebar di sekitar garis diagonal dan tidak ada data yang menyebar jauh dari garis diagonal. Dengan demikian, asumsi normalitas dapat dipenuhi atau data yang yang diperoleh berasal dari populasi yang berdistribusi normal (Gustomo et al., 2011; Izuchukwu, 2011; Syauta dan Widjaja, 2009; Tarmizi, 2007). Dengan mengadopsi metode luas daerah di bawah kurva normal, diperoleh bahwa sekitar 95\% dari luas daerah di bawah kurva normal terletak antara $\mathrm{m} \pm 2 \mathrm{~s}$, sehingga dari histogram dan kurva normal pada Gambar 2 dapat disimpulkan bahwa data berdistribusi normal (Gujarati, 1988).

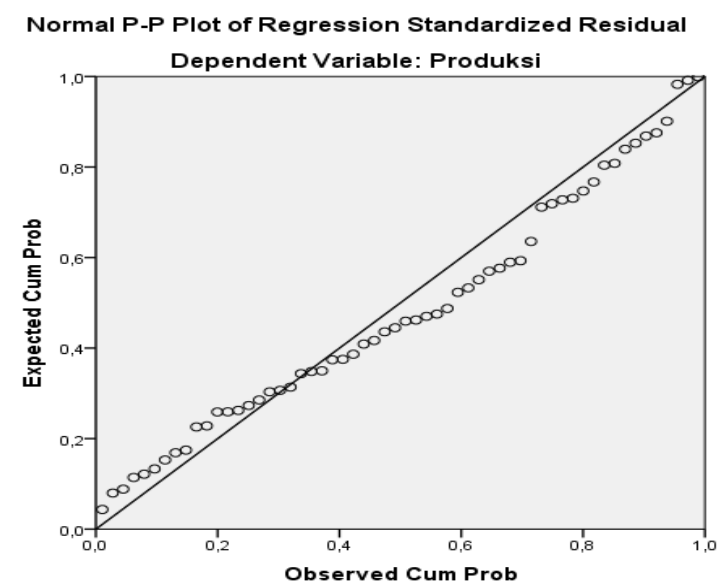

Gambar 1. Scatter Plot Uji Normalitas

\section{Uji Heteroskedastisitas}

Salah satu metode yang umum digunakan untuk mendeteksi gangguan hetero-skedastsitas adalah dengan metode grafik (diagram pencar) residual, yaitu selisih antara nilai produksi prediksi $(\hat{Y} \hat{Y})$ dan nilai produksi observasi (Y). Karena diagram pencar pada Gambar 3 tidak membentuk pola tertentu atau tersebar secara acak, maka model regresi tidak mengalami masalah heteroskedastisitas (Supriana dan Nasution, 2010; Pratisto, 2009).

\section{Uji Multikolinieritas}

Multikolinearitas adalah keadaan dimana terjadi korelasi yang erat antarvariabel bebas dalam model regresi majemuk. Ada tidaknya multikolinieritas dalam suatu model regresi majemuk dapat dilihat dari nilai tolerance atau VIF (variance inflation factor) dari masing-masing variabel.

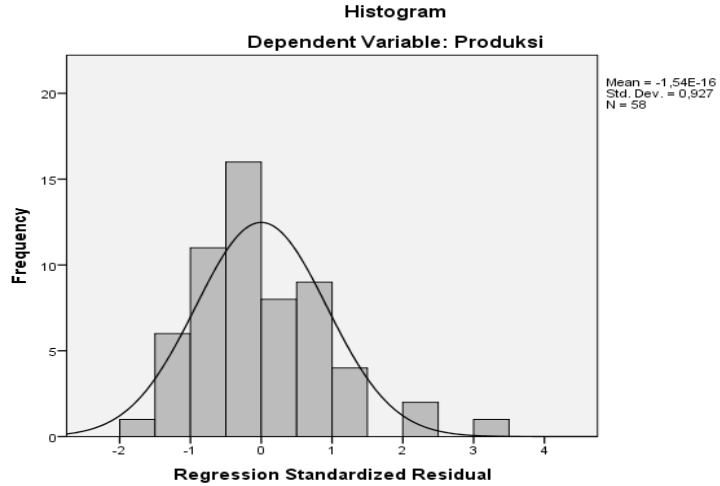

Gambar 2. Histogram dan Kurva Normal 
VIF merupakan ukuran yang menggambarkan seberapa banyak variasi koefisien regresi meningkat jika antarvariabel bebas berkorelasi. Dasar pengambilan keputusan adalah: jika nilai tolerance $>0,1$ atau VIF $<$ 10 maka tidak terdapat multikolinieritas dalam model yang disusun (Alipour, 2011). Berdasarkan output SPSS, semua nilai tolerance lebih besar dari 0,1 dan nilai VIF lebih kecil dari 10, sehingga dapat disimpulkan bahwa tidak terdapat masalah multikolinieritas di antara variabel bebas.

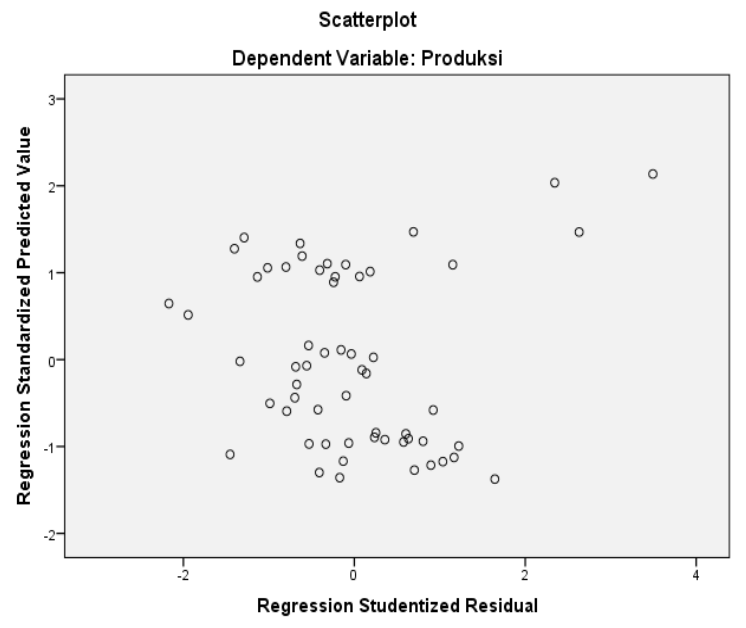

Gambar 3. Scatter Plot Uji Heteroskedastisitas

\section{Uji Kesesuaian Model}

Uji kesesuaian model regresi majemuk merupakan ukuran apakah model yang disusun dapat digunakan dan dilanjutkan estimasinya. Statistik yang digunakan untuk melihat apakah suatu model $f i t$ atau tidak adalah koefisien determinasi $\left(\mathrm{R}^{2}\right)$ yang diuji dengan melihat nilai sig dari statistik F. Dari output SPSS diperoleh bahwa $\mathrm{R}^{2}$ adalah 0,526 dengan nilai sig dari statistik $F=0,000$. Karena nilai sig lebih kecil dari a (1\%), maka persamaan regresi merupakan model yang sesuai (Gujarati, 1988; Pratisto, 2009) dan dapat digunakan untuk menduga koefisien regresi dan menentukan pengaruh semua variabel bebas terhadap produksi kopi arabika.

\section{Uji ANOVA}

Uji ANOVA digunakan untuk mengetahui pengaruh seluruh variabel bebas dalam aspek sosial dan ekologi secara bersama terhadap produksi kopi arabika. Dengan statistik F sebesar 8,916 dan nilai sig $=0,000$, dapat disimpulkan bahwa semua variabel bebas secara bersama berpengaruh sangat nyata terhadap produksi kopi arabika. Bila dikaitkan dengan nilai $\mathrm{R}^{2}$ sebesar 0,526, maka $52,60 \%$ variasi dalam produksi kopi arabika dapat dijelaskan oleh semua variabel bebas yang dimasukkan ke dalam model; sementara 47,40\% lainnya dijelaskan oleh variabel yang tidak dimasukkan ke dalam model. Diduga kuat bahwa sebagian besar dari 47,40\% ini merupakan porsi dari aspek ekonomi dalam usahatani kopi arabika, seperti luas lahan, tenaga kerja, dan modal (Saragih, 2012b).

\section{Aspek Sosioekologis Usahatani Kopi Arabika}

Aspek sosial yang berpengaruh nyata terhadap produksi kopi arabika adalah partisipasi petani mengikuti pelatihan usahatani. Dua aspek lainnya, umur dan pendidikan formal, berpengaruh positif namun tidak nyata terhadap produksi (Tabel 1). Dengan demikian, pelatihan usahatani merupakan aspek penting dalam usahatani kopi di dataran tinggi Kabupaten Simalungun. Beberapa jenis pelatihan usahatani kopi arabika yang pernah diikuti petani adalah manajemen usahatani, pengendalian hama dan penyakit, pemangkasan tanaman kopi, manfaat pohon pelindung, dan pencatatan aktivitas usahatani.

Penelitian ini menemukan faktor penting penentu produksi dari aspek sosial. Pendidikan nonformal dalam bentuk pelatihan berpengaruh sangat nyata terhadap produksi kopi arabika. Tingkat partisipasi petani mengikuti pelatihan usahatani kopi arabika masih 38\% dengan rata-rata mengikuti pelatihan dua kali per tahun. Arnawa et al. (2010) menemukan bahwa pembinaan dilakukan melalui pelatihan, di kelas dan lapangan, yang bertujuan untuk meningkatkan produksi dan mutu produk.

Tabel 1. Hasil Pendugaan Parameter Model Regresi Majemuk

\begin{tabular}{lcccccc}
\hline \multicolumn{1}{c}{ Variabel } & $\begin{array}{c}\text { Koefisien } \\
\text { regresi }\end{array}$ & Simpangan baku & t-hitung & Sig. & Tolerance & VIF \\
\hline Konstanta & 308,276 & 634,791 & 0,486 & 0,629 & -- & -- \\
Umur & 2,696 & 9,538 & 0,283 & 0,779 & 0,650 & 1,539 \\
Pendidikan & 4,789 & 30,837 & 0,155 & 0,877 & 0,641 & 1,560 \\
Pelatihan & $616,978^{* *}$ & 227,000 & 2,718 & 0,009 & 0,433 & 2,310 \\
Pelindung legum & $432,833^{*}$ & 174,427 & 2,481 & 0,017 & 0,900 & 1,111 \\
Jumlah Pelindung & 1,498 & 1,370 & 1,093 & 0,280 & 0,649 & 1,541 \\
Pemangkasan & $572,024^{* *}$ & 209,825 & 2,726 & 0,009 & 0,486 & 2,056 \\
Pupuk Organik & 134,619 & 335,362 & 0,401 & 0,690 & 0,727 & 1,375 \\
Kulit Kopi sebagai Mulsa & 210,087 & 193,189 & 1,087 & 0,282 & 0,574 & 1,743 \\
\hline
\end{tabular}

Keterangan: * dan ** berarti variabel bebas berpengaruh nyata $(\mathrm{a}=0,05)$ dan sangat nyata $(\mathrm{a}=0,01)$ terhadap produksi kopi arabika, lainnya tidak berpengaruh nyata 
Setelah pelatihan para petani yang bergabung dalam UKM dapat meningkatkan omzet dan investasi sebesar $10 \%$ serta memperluas cakupan pemasaran. Untuk meningkatkan produktivitas kopi rakyat melalui perawatan kopi dan optimalisasi penggunaan input, Maridelana et al. (2014) merekomendasikan peningkatan pelatihan dan bimbingan teknis bagi para petani kopi.

Jumlah pohon pelindung legum berpengaruh nyata terhadap produksi kopi arabika. Dengan demikian, aspek pohon pelindung tidak hanya terkait dengan populasi pohon pelindung per satuan luas lahan, akan tetapi yang terpenting adalah jenis pohon pelindung yang ditanam petani. Pohon pelindung legum dapat memperoleh $\mathrm{N}$ dari udara sebagai hasil penangkapan secara biologis oleh bakteri bintil akar. Agroekosistem berpelindung pohon gamal atau dadap memberi hasil kopi yang lebih tinggi daripada kopi tanpa pelindung dan kopi berpohon pelindung cempaka (Evizal et al., 2008).

Jumlah pohon pelindung tidak berpengaruh nyata terhadap produksi kopi arabika, dengan nilai koefisien sebesar 1,498. Secara statistik p-value (sig) yang lebih besar dari tingkat $\mathrm{a}=5 \%$ yaitu $0,280>0,05$. Hal ini menunjukkan bahwa semakin banyak populasi pohon pelindung pada tanaman kopi arabika cenderung meningkatkan produksi kopi arabika, namun tidak signifikan. Jumlah populasi pohon pelindung yang semakin banyak mengakibatkan penurunan intensitas cahaya sehingga mengurangi proses fotosintesis yang akan mengakibatkan pelambatan produksi.

Jumlah pohon pelindung pada perkebunan kopi di Kabupaten Simalungun masih relatif rendah yaitu rata-rata 67 pohon/ha. Hasil penelitian Rosalia dan Ratnasari (2016) mengenai hutan kemasyarakatan (Hkm) di Kabupaten Tanggamus Provinsi Lampung dapat diadopsi dan dimodifikasi untuk meningkatkan populasi pohon pelindung di wilayah penelitian ini. Pengembangan hutan kemasyarakatan (HKm) berbasis kebun kopi arabika melalui pendampingan dan fasilitasi para pemangku kepentingan bagi kelompok tani dapat meningkatkan jumlah populasi pohon pelindung.

Hasil penelitian ini senada dengan Vossen (2005). Pohon pelindung berfungsi sebagai pencegah terjadinya over-bearing karena pengurangan intensitas cahaya. Yadessa et al. (2008) dan Moreira et al. (2008) menemukan bahwa pohon pelindung lebih berpengaruh signifikan pada kualitas kopi. Bahkan, Elevitch et al. (2009) menyimpulkan tingkat naungan yang lebih tinggi akan menurunkan produksi kopi.

Salah satu kelemahan mendasar pada usahatani kopi arabika di wilayah penelitian adalah jumlah pohon pelindung masih sangat sedikit, hanya 67 pohon per ha. Jika dibandingkan dengan kriteria umum jumlah pelindung minimal untuk tanaman kopi yaitu 400 pohon/ ha (Zaenudin, 2009) untuk jenis lamtoro (Leucaena glauca) atau gamal (Glirisidia sepium) atau 200-300 pohon/ha (Mawardi et al., 2008); maka jumlah populasi pohon pelindung pada kebun kopi di lokasi penelitian masih sangat rendah.

Jumlah pohon pelindung yang masih sedikit pada usahatani kopi arabika tidak terlepas dari penilaian petani tentang manfaat pohon pelindung. Saragih (2013) menemukan bahwa sebagian besar petani $(40 \%)$ belum mengetahui manfaat pohon pelindung bagi tanaman kopi dan konservasi lahan. Sebagian petani (16\%) menyatakan manfaat pohon pelindung untuk menaungi tanaman kopi dari sinar matahari langsung, $12 \%$ untuk pelestarian lingkungan/konservasi lahan, dan $4 \%$ bermanfaat ganda sebagai penahan sinar matahari dan angin, mengurangi serangan hama dan penyakit, dan meningkatkan kualitas kopi.

Manfaat ekologis usahatani kopi dengan tanaman pelindung antara lain adalah konservasi tanah dan air, pengendalian hama dan penyakit, dan antisipasi perubahan iklim (climate change). Di Indonesia, kebun kopi dengan pohon pelindung sistem lorong (alley cropping) mampu mengurangi erosi tanah sebesar 64\% dibandingkan dengan kebun kopi tanpa pohon pelindung. Di Nikaragua, kehilangan tanah pada usahatani kopi tanpa pelindung 2,5 kali lebih besar dibandingkan dengan usahatani kopi berpelindung pada tingkat kemiringan yang sama (Rice, 2010).

Praktik pemangkasan tanaman kopi berpengaruh positif dan sangat nyata terhadap produksi kopi arabika, dengan nilai koefisien 572,024. Hal ini menunjukkan bahwa kegiatan pemangkasan tanaman kopi yang dilakukan petani memiliki peran penting dalam peningkatan produksi. Kadir et al. (2004) menemukan bahwa pemangkasan tanaman kopi berperan dalam memperbaiki pertumbuhan dan komponen produksi tanaman kopi (jumlah cabang produktif, jumlah ruas produktif, dan jumlah bunga tanaman kopi).

Penggunaan pupuk organik tidak berpengaruh nyata terhadap produksi kopi arabika, dengan nilai koefisien sebesar 134,619. Nilai $p$-value (sig) yang lebih besar dari tingkat $\mathrm{a}=5 \%$ atau $0,082>0,05$. Kadir dan Kanro (2006) menemukan bahwa pemberian pupuk organik pada tanaman kopi tidak menunjukkan perbedaan yang signifikan untuk variabel jumlah cabang produksi bila dibandingkan dengan tanaman kopi tanpa pupuk organik. Hasil yang sama ditemukan oleh Rubiyo et al. (2004), dimana pemberian pupuk organik dengan dosis yang berbeda tidak berpengaruh nyata terhadap produksi kopi gelondong per pohon dan jumlah buah per dompol.

Pengembalian kulit kopi sebagai mulsa ke kebun tidak berpengaruh nyata terhadap produksi kopi arabika. Namun, menurut Arnawa et al. (2010), pemanfaatan limbah kulit buah kopi mampu meningkatkan keuntungan 4,5\%-7,5\% per tahun. Sementara Abdoellah (2002) menemukan bahwa mulsa kulit kopi sebanyak $25 \mathrm{dm}^{3} /$ pohon tidak dapat meningkatkan produksi kopi. 
Berkaitan dengan peningkatan pemangkasan tanaman kopi, penggunaan pupuk organik, dan mulsa kulit kopi, diperlukan pendekatan baru dari hanya sekedar penyampaian informasi mengenai manfaat ekologisnya. Hijjang et.al. (2014) menemukan bahwa mengintegrasikan pengetahuan lokal dan kreatifitas petani, baik yang bersumber dari tradisi lokal maupun yang dari luar dan melibatkan semua stakeholder dalam setiap kegiatan pertanian dapat membangun petani yang berjiwa agroecopreneur dan arif lingkungan.

\section{SIMPULAN}

Aspek sosial yang berperan penting dalam usahatani kopi arabika adalah umur, pendidikan, dan partisipasi petani mengikuti pelatihan usahatani. Partisipasi petani dalam pelatihan usahatani berpengaruh nyata terhadap produksi kopi arabika. Temuan penting penelitian ini adalah bahwa petani yang pernah mengikuti pelatihan usahatani yaitu pelatihan mengenai manajemen usahatani, pengendalian hama dan penyakit, serta pemangkasan tanaman kopi dapat menghasilkan produksi yang lebih tinggi secara nyata dibandingkan dengan petani yang belum pernah mengikuti pelatihan sejenis. Sementara umur dan pendidikan formal kepala keluarga tidak berpengaruh nyata terhadap produksi kopi arabika.

Aspek ekologi yang penting dalam usahatani kopi arabika adalah jumlah pohon pelindung jenis legum, jumlah pohon pelindung, pemangkasan tanaman kopi, penggunaan pupuk organik, dan pengembalian kulit kopi ke kebun sebagai mulsa. Usahatani yang memiliki pohon pelindung jenis legum dapat menghasilkan produksi lebih tinggi dari pada pohon pelindung nonlegum. Demikian halnya dengan praktik pemangkasan tanaman kopi yang memberikan pengaruh positif dan nyata terhadap produksi.

Aspek sosial dan ekologis yang berkaitan dengan usahatani kopi arabika masih memerlukan peningkatan. Umur petani masih dalam kelompok produktif dengan rata-rata 40 tahun, namun pendidikan formal masih relatif rendah, hanya rata-rata 10 tahun. Keikutsertaan petani mengikuti pelatihan, yang merupaka aspek sosial penting dalam usahatani kopi arabika, masih rendah dengan tingkat partisipasi haya 30\%. Aspek ekologis yang perlu ditingkatkan karena masih rendah adalah penggunaan pohon pelindung legum (26\%), jumlah pohon pelindung (67 pohon/ha), pemangkasan tanaman kopi (43\%), pengembalian kulit kopi sebagai mulsa (57\%), dan menyediakan tempat terpisah untuk menyimpan pestisida (41\%). Sementara aspek ekologis yang sudah baik adalah penggunaan pupuk organik (93\%) dan penggunaan masker atau pengaman saat mengaplikasikan pestisida (67\%). Aspek ekologis yang perlu diminimalkan adalah penggunaan herbisida untuk mengendalikan gulma (91\%).
Para pemangku kepentingan kopi arabika, yaitu Dinas Perkebunan, organisasi nonpemerintah, dan perguruan tinggi, perlu meningkatkan frekuensi dan kualitas pelatihan usahatani kopi arabika terutama untuk petani kopi berusia produktif. Disamping itu, diperlukan peningkatan motivasi dan pelatihan pemangkasan tanaman kopi bagi petani. Dinas Perkebunan dan organisasi nonpemerintah sebaiknya menyediakan pohon pelindung jenis legum untuk ditanam petani sebagai pohon pelindung kopi arabika.

\section{DAFTAR PUSTAKA}

Abdoellah, S. 2002, Pengaruh Irigasi Tetes Sederhana Bertekanan Rendah dan Mulsa pada Tanaman Kopi Robusta, Pelila Perkebunan 18(2), 77-83.

Alipour, M. 2011, Working Capital Management and Corporate Profitability: Evidence from Iran. World Applied Sciences Journal, 12(7), 10931099.

Arnawa, I. K., Martiningsih, N.G.A.G.E., Budiasa, I.M., Sukarna, I.G. 2010, Pemanfaatan Limbah Kulit Buah Kopi Arabika dalam Upaya Peningkatan Keuntungan UKM dan Pelestarian Lingkungan, Majalah Aplikasi Ipteks Ngayah, 1(1), 89-96.

Ditjen Perkebunan, 2015, Statistik Kopi Indonesia, http://www.ditjenbun.go.id.

Elevitch, C., Idol, T., Friday, J.B., Lepczyk, C., Smith, V.E., Nelson, S.C. 2009, Shade-grown Coffee for Hawaii: Results of a Twelve Farm Study in Kona, Permanent Agriculture Resources (PAR), Holualoa, Hawaii. http:/www.agroforestry.net/ caf

Evizal, R., Tohari, Prijambada, I.D., Widada, Widianto, D., 2008, Layanan Lingkungan Pohon Pelindung pada Sumbangan Hara dan Produktivitas Agro ekosistem Kopi, Pelita Perkebunan, 25(1), 2337.

Gregory, A., Featherstone, A.M. 2008, Nonparametric Efficiency Analysis for Coffee Farms in Puerto Rico, Selected Paper Prepared for Presentation at the Southern Agricultural Economics Association Annual Meeting, Dallas.

Gujarati, D. N. 1988. Basic econometrics, McGrawHill Book Company.

Hijjang, P., Lampe, M., dan Basir, M., 2014, Aneka Ragam Pengetahuan Lokal dan Kreativitas Petani yang mendukung Agroecopreneuer Ramah Lingkungan di Sulawesi Selatan, Sosiohumaniora, 16(2), 143-148.

Izuchukwu, O. 2011, Analysis of the Contribution of Agricultural Sector on the Nigerian Economic 
Development, World Review of Business Research, 1(1), 191-200.

Kadir, S., Darmawidah, A., Kanro, M.Z. 2004, Pengaruh Pemangkasan terhadap Pertumbuhan dan Komponen Produksi Tanaman Kopi, Jurnal Agrivigor, 4(1), 15-20.

Kadir, S., Kanro, M.Z. 2006, Pengaruh Pupuk Organik terhadap Pertumbuhan dan Produksi Kopi Arabika, Jurnal Agrivigor, 6 (1), 85-92.

Ludi, E. \& Amsalu, A., 2010, The effect of Global Coffee Price Changes on Rural Livelihoods and Natural Resource Management in Ethiopia: A Case Study from Jimma Area, NCCR NorthSouth Dialogue No. 26.

Malta, 2016, faktor-Faktor yang Berhubungan dengan Kemandirian Petani dalam Pengambilan Keputusan untuk Keberlanjutan Usahatani (Kasus: Petani di Desa Sukaharja - Kabupaten Bogor), Sosiohumaniora, 18(2), 118-124.

Maridelana, V.P., Hariyati, Y., Kuntadi, E.B. 2014, Fungsi Keuntungan Usahatani Kopi Rakyat di Desa Belantih Kecamatan Kintamani Kabupaten Bangli, Berkala Ilmiah Pertanian, 1(3), 47-52.

Mawardi, S., Hulupi, R., Wibawa, A., Wiryadiputra, S., Yusianto. 2008, Panduan Budidaya dan Pengolahan Kopi Arabika Gayo, Pusat Penelitian Kopi dan Kakao Indonesia, APED, Bappeda NAD dan UNDP, Banda Aceh.

Moreira, C.F., Fernandes, E.D.N., Tagliaferro, F.S. 2008, Shaded Coffee: A Way to Increase Sustainability in Brazilian Organic Coffee Plantations.

Pratisto, A. 2009, Statistik Menjadi Mudah dengan SPSS 17, Elex Media Komputindo.

Rice, R. 2010, The Ecological Benefits of Shade-grown Coffee: The Case for Going Bird Friendly ${ }^{\circledR}$, Washington: Smithsonian Migratory Bird Center (SMBC)-National Zoological Park.

Rosalia, F. dan Ratnasari, Y., 2016, Analisis Pengelolaan Hutan Kemasyarakatan di Sekitar Kawasan Hutan Lindung Register 30 Kabupaten Tanggamus Provinsi Lampung Tahun 2010, Sosiohumaniora, 18(1), 34-38.

Rubiyo, Trisnawati, W., Guntoro, S., Destialisma. 2004, Pengaruh Dosis Pupuk Kandang Sapi terhadap Produktivitas dan Mutu Kopi Arabika di Bali, Prosiding Seminar Nasional Sistem Integrasi Tanaman Ternak, Puslitbangnak Bogor, 396-400.
Saragih, J.R. 2012a, Pengaruh Faktor Sosial Ekonomi dan Ekologi terhadap Produksi Kopi Arabika Spesialti dalam Pengembangan Ekonomi Lokal di Kabupaten Simalungun, Disertasi, Sekolah Pascasarjana, Universitas Sumatera Utara.

Saragih, J.R. 2012b, Model Pengembangan Ekonomi Lokal (PEL) berbasis Produktivitas Kopi Arabika Spesialti di Kabupaten Simalungun, Wahana Hijau: Jurnal Perencanaan dan Pengembangan Wilayah, 7(3), 117-125.

Saragih, J.R. 2013, Sistem Usahatani Kopi Berpelindung dan Multistrata sebagai Strategi Konservasi Lahan di Sumatera Utara, Makalah pada Sarasehan untuk Peringatan Hari Penanggulangan Degradasi Lahan dan Kekeringan Dunia, Toba Samosir, 17 Juni 2013.

Supriana, T., Nasution, V.L. 2010, Peran Usaha TKI Purna terhadap Pengembangan Ekonomi Lokal dan Faktor yang Mempengaruhi Pendapatan Usaha TKI Purna di Provinsi Sumatera Utara, Makara Sosial Humaniora, 14(1), 42-50.

Tarmizi, A. 2007, Faktor-faktor yang Memengaruhi Efisiensi Saluran Pemasaran Karet Rakyat di Jambi, Jurnal Aplikasi Manajemen, 5(3), 412417.

Vossen, H. A. M. V., 2005, A Critical Analysis of the Agronomic and Economic Sustainability of Organic Coffee Production, Experimental Agriculture, 41, 449-473.

Widjaja, I. \& Syauta, R.C., 2009, Analisis Pengaruh Rasio ROA, LDR, NIM, dan NPL terhadap Abnormal Return Saham Perbankan di Indonesia pada Periode Sekitar Pengumuman Subprime Mortgage, Journal of Applied Finance and Accounting, 1(2), 351-367.

Yadessa, A., Burkhardt, J., Denich, M., Gole, T.W., Bekele, B., Goldbach, H. 2008, Effect of Different Indigenous Shade Trees on Quality of Wild Arabica Coffee in the Afromontane Rainforest of Ethiopia. Poster presented at 22nd International Conference on Coffee Science (ASIC), Campinas-Brazil.

Zaenudin, 2009, Good Agricultural Practices and Sustainable Coffee Production, Modul Training of Trainers Course, IFC and PT. Indo Cafco, Medan. 